\title{
Does Dihydropyrimidine Dehydrogenase Level Modify Plasma Antioxidant Capacity in Colorectal Cancer Patients Treated with Fluoropyrimidines?
}

\author{
Velko Minchev $^{1}$, Nadya Hristova-Avakumova ${ }^{2}$, Kalina Kamenova ${ }^{3}$, Liliya Atanasova ${ }^{2}$, Marin Angelov ${ }^{1}$, \\ Lozan Todorov ${ }^{4}$, Slavina Surcheva ${ }^{5}$, Rumen Nikolov ${ }^{5}$ \\ ${ }^{1}$ Department of Oncology, Sofiamed University Hospital, Sofia, Bulgaria \\ ${ }^{2}$ Department of Medical Physics and Biophysics, Faculty of Medicine, Medical University of Sofia, Sofia, Bulgaria \\ ${ }^{3}$ Department of Medical Chemistry and Biochemistry, Faculty of Medicine, Medical University of Sofia, Sofia, Bulgaria \\ ${ }^{4}$ Department of Chemistry, Faculty of Pharmacy, Medical University of Sofia, Sofia, Bulgaria \\ ${ }^{5}$ Department of Pharmacology and Toxicology, Faculty of Medicine, Medical University of Sofia, Sofia, Bulgaria
}

Corresponding author: Nadya Hristova-Avakumova, Department of Medical Physics and Biophysics, Faculty of Medicine, Medical University of Sofia, Sofia, Bulgaria; E-mail: nadia_hristova@abv.bg; Tel.: +359 885848954

Received: 4 Aug $2020 \diamond$ Accepted: 21 Oct $2020 \diamond$ Published: 31 Oct 2021

Citation: Minchev V, Hristova-Avakumova N, Kamenova K, Atanasova L, Angelov M, Todorov L, Surcheva S, Nikolov R. Does dihydropyrimidine dehydrogenase level modify plasma antioxidant capacity in colorectal cancer patients treated with fluoropyrimidines? Folia Med (Plovdiv) 2021;63(5):760-7. doi: 10.3897/folmed.63.e57234.

\begin{abstract}
Introduction: Colorectal cancer is the third most common cancer type worldwide. Fluoropyrimidines and their prodrug-based regimens are widely applied as primary medications. The main enzyme responsible for the rate-limiting step in pyrimidine and for the 5-fluorouracil catabolism is dihydropyrimidine dehydrogenase (DPD).
\end{abstract}

Aim: We aimed to screen DPD level and the changes of plasma antioxidant capacity of colorectal cancer patients on 5-fluorouracil regimen.

Materials and methods: Human DPD Elisa Kit based on sandwich enzyme-linked immune-sorbent assay and spectrophotometric methods (FRAP and ABTS) were used in the study.

Results: No statistically significant changes in plasma scavenging activity according to the results obtained in the ABTS system have been observed after evaluating all patients and considering DPD concentration. A decrease of the ferric reducing ability of patients' plasma taken after the administered treatment was found. The increase of DPD level is accompanied by a decrease in the $p$ values and therefore the statistical significance of the differences increases.

Conclusions: Based on the aforementioned observations, it could be concluded that some aspects of plasma antioxidant capacity and individuals' antioxidant status might be involved in the pathogenesis of the disease and could be altered by the activity of some enzymes. The cancer therapy in question, by the specificity of its mechanism of action, can modify patient's oxidative status.

\section{Keywords}

ABTS, colorectal cancer, dihydropyrimidine dehydrogenase, fluoropyrimidines, FRAP

Copyright by authors. This is an open access article distributed under the terms of the Creative Commons Attribution License (CC-BY 4.0), which permits unrestricted use, distribution, and reproduction in any medium, provided the original author and source are credited. 


\section{INTRODUCTION}

Colorectal cancer (CRC) is the third most common cancer type worldwide and the fourth most common cause of death according to GLOBOCAN 2018. CRC usually develops from the glandular epithelial cells lining the large intestine, which are known to divide rapidly and have high metabolic rate. The disease affects men and women almost equally and in $70 \%$ to $80 \%$ of the cases it occurs sporadically. Survival rate highly depends on the stage, $70 \%$ for regional to $10 \%$ for patients with distant metastatic cancer. ${ }^{1}$ Due to inconspicuous early symptoms, most patients are diagnosed in the advanced stage of the disease, which is associated with lowering of the success of surgical intervention and poor prognosis. Many factors have been pointed to potentially contribute to an increased risk of colorectal cancer including obesity, high-meat, high-calorie, fat-rich diet, smoking, age, family history of CRC, and overconsumption of alcohol. The main strategies for treatment depend on the disease stage and are comprised of a combination between surgical procedure with chemotherapy and/or radiotherapy. ${ }^{2,3}$

Oxidative stress has been demonstrated as one of the risk and contributing factors of the pathophysiological mechanism of colorectal carcinogenesis. It is a well-known fact that cancer patients exhibit changes in their antioxidant status and antioxidant defense systems. ${ }^{4}$ Alterations in the quantity of both the low molecular weight substances with antioxidant effect and the enzymatic antioxidants have been observed quite often. ${ }^{5}$

Apart from this, additional increase of ROS generation in patients' bodies might be observed as a result of the applied chemotherapeutic treatment suggesting increased oxidative stress compared to that induced by the cancer disease itself. This could be associated with the mechanism of action of the drugs and/or by its interference with some of the compensatory oxidative stress mechanisms.

Fluoropyrimidines and their prodrug-based regimens are widely applied as primary medications in the treatment of colorectal cancer. Dyhydropyrimidine dehydrogenase is a ubiquitous enzyme, mostly represented in the liver. It is responsible for the rate-limiting step in pyrimidine and respectively in 5-fluorouracil (5-FU) catabolism. That makes it essential for treatment efficacy and associated toxic reactions. ${ }^{6}$ In many studies, application of regimens including fluoropyrimidines has been associated with increased reactive oxygen species generation, oxidative molecular damage and suppression of the antioxidant defense system. ${ }^{7-9}$

\section{AIM}

From this point of view obtaining additional information concerning therapy, dosage, potency for metabolization, efficacy and toxicity is an important task when discussing strategies for personalized treatment.
Herein we present results from the first pilot study concerning estimation of the DPD level of Bulgarian patients with histologically proven diagnosis of colorectal cancer receiving 5-FU. We screened their DPD levels and the changes of their plasma antioxidant capacity.

\section{MATERIALS AND METHODS}

The study was conducted within a period of six months from July 2019 to February 2020 - in the Department of Oncology of Sofiamed University Hospital. The inclusion criteria involved patients aged between 18 and 80 years willing to give blood samples for the purpose of the study, to provide a signed voluntary informed consent to participate and to complete a structured questionnaire, including information about their smoking and eating habits. All patients with any other serious comorbidity or those who have received any other pharmaceutical products that could influence the studied parameters were excluded from the study. Medical histories based on the information provided by the patients accompanying their medical records and the patients' objective condition were assessed. The diagnostic methods applied include full blood count and general biochemistry tests, imaging methods (lung and heart X-ray, abdominal ultrasound, computed tomography, nuclear magnetic resonance) and histological verification. Blood samples were collected from 38 patients by venous puncture using heparinized tubes at baseline and before the infusion of the drug from the next cycle of treatment.

\section{Dihydropyrimidine dehydrogenase estimation}

Human DPD Elisa Kit based on sandwich enzyme-linked immune-sorbent assay was used. This method is based on detection of the pre-coated anti-DPD antibody onto 96 well plates via biotin conjugation. On the basis of the measured absorbance at $450 \mathrm{~nm}, \mathrm{DPD}$ concentration [ng/ml] was calculated.

\section{Antioxidant capacity estimation}

\section{ABTS assay}

Plasma total antioxidant capacity was estimated by the method described by Re et al. ${ }^{10}$ The method is based on decolorization of the blue-green solution of the preformed stable ABTS cation radical which has absorbance maximum at 650,734 , and $820 \mathrm{~nm}$. The observed decline of the absorbance at $734 \mathrm{~nm}$ indicates the level of eliminated radicals and is directly related to the antioxidant capacity of the patients' plasma. The radical solution was prepared by mixing equal parts (v/v) $14 \mathrm{mM}$ ABTS stock solution and potassium persulfate $2.45 \mathrm{mM}$ (final concentration) the day before the experiments. The obtained solution was stored for 16 to 18 hours in dark at $4^{\circ} \mathrm{C}$. The working solution of 
the radical was prepared by dissolving the stock solution until an absorbance of $0.700 \pm 0.005$ at $734 \mathrm{~nm}$ was achieved. Two types of samples with equivalent radical concentrations were prepared: controls with no plasma and samples containing the patients' plasma. The obtained results were presented as RSA [\%] (the ratio in percentages between the subtraction of the absorbance of the sample containing plasma from that of the control sample on one hand and the absorbance of the control on the other).

$$
R S A, \%=\frac{A_{\text {control }}-A_{\text {sample }}}{A_{\text {control }}} * 100
$$

\section{FRAP assay}

The procedure was performed according to Benzie and Stain. ${ }^{11}$ The method is based on the reduction of the ferric-tripyrydyltriazine complex (Fe $\left.\mathrm{FII}^{\mathrm{II}} \mathrm{TPTZ}\right)$ to its ferrous, blue colored form (Fe $\mathrm{Fe}^{\mathrm{II}} \mathrm{TPTZ}$ ) by plasma antioxidants. The working FRAP reagent solution was prepared by mixing $300 \mathrm{mM}$ acetate buffer (pH 3.6), $10 \mathrm{mM}$ 2,4,6-Tripyridyl-s-triazine (TPTZ) solution (in $40 \mathrm{mM} \mathrm{HCl}$ ) and 20 $\mathrm{mM} \mathrm{FeCl} 3 \cdot 6 \mathrm{H}_{2} \mathrm{O}$ in a 10:1:1 ratio. Final plasma dilution in the reaction mixture was $1 / 34$. The mixture is prepared just before use and heated to $37^{\circ} \mathrm{C}$. The absorbance, exactly 4 min after starting the reaction, of the obtained blue colored product and the blank were determined at $593 \mathrm{~nm} .1$ $\mathrm{mmol} / \mathrm{L} \mathrm{FeSO}_{4}$ was used as a standard solution. The results were expressed as millimoles of $\mathrm{Fe}^{\mathrm{II}}$ equivalents using $\mathrm{FeSO}_{4}$ calibration curve.

\section{Statistical analysis}

All measurements were performed in triplicates and the obtained values were expressed as mean \pm SD. The significance of the observed differences was estimated using parametric statistical methods. Data sets were compared using paired sample t-test. Levels of significance of $p<0.05$ were accepted. Data were presented as "box and whiskers" plots: each box summarizes data from 38 values corresponding to 38 patients (each individual value being mean of triplicate measurements). Each plot is bordered at the first (Q1) and third (Q3) quartile of the variable and is cut by a horizontal line corresponding to the median. Whiskers correspond to minimal and maximal value.

\section{RESULTS}

\section{Clinical characteristics}

Thirty-eight patients were included in the present study. The baseline clinical characteristics of the recruited patients with histologically confirmed diagnosis of colorectal cancer are summarized in Table 1. The 38 patients with CRC were distributed equally among women and men. The ma-
Table 1. Clinical and histopathological features of colorectal cancer patients

\begin{tabular}{|c|c|c|}
\hline Patients $(n=38)$ & & \\
\hline \multirow{2}{*}{ Gender } & Male & 19 \\
\hline & Female & 19 \\
\hline \multirow{3}{*}{ Age } & Mean & 64 \\
\hline & Median & 68 \\
\hline & Range & $43 \leftrightarrow 80$ \\
\hline \multirow{2}{*}{ Site } & Colon & 22 \\
\hline & Rectum & 16 \\
\hline \multirow{4}{*}{ Tumor stage } & Stage I & 0 \\
\hline & Stage II & 8 \\
\hline & Stage III & 13 \\
\hline & Stage IV & 17 \\
\hline \multirow{3}{*}{ Histological grading } & Low & 5 \\
\hline & Medium & 31 \\
\hline & High & 2 \\
\hline \multirow{8}{*}{$\mathrm{DPD}[\mathrm{ng} / \mathrm{ml}]$} & $<0.15$ & 5 \\
\hline & $0.15 \leftrightarrow 0.27$ & 5 \\
\hline & $0.27 \leftrightarrow 0.39$ & 9 \\
\hline & $0.39 \leftrightarrow 0.51$ & $\begin{array}{l}2 \text { (all higher } \\
\text { than the mean) }\end{array}$ \\
\hline & $0.51 \leftrightarrow 0.63$ & 4 \\
\hline & $0.63 \leftrightarrow 0.75$ & 7 \\
\hline & $0.75 \leftrightarrow 0.87$ & 4 \\
\hline & $>0.87$ & 2 \\
\hline
\end{tabular}

jority were in stage three and stage four $(34.2 \%$ and $44.7 \%$, respectively) and none of them was stage one. This is indicative for the presence of local (stage III) and distant (stage IV) metastasis and correlates with the observed worldwide tendency for diagnosis in the advanced stage of the disease. $81.6 \%$ of the studied patients were in medium grade.

The median and mean DPD levels are, respectively, 0.42 $\mathrm{ng} / \mathrm{ml}$ and $0.46 \mathrm{ng} / \mathrm{ml}$. Based on patients' DPD level distribution and the method range we divided our 38 patients into three groups: group I (patients with DPD lower than $0.15 \mathrm{ng} / \mathrm{ml}, 5$ patients); group II (patients with DPD in the interval between 0.15 to $0.39 \mathrm{ng} / \mathrm{ml}, 14$ patients), and group III (patients with DPD higher than $0.39 \mathrm{ng} / \mathrm{ml}, 19$ patients). The unequal distribution of colorectal cancer patients was also described in the study of van Kuilenburg and coworkers. They postulated the term threshold limit for the DPD activity as $70 \%$ of the mean DPD activity of a control population expressed as $\mathrm{nmol} / \mathrm{mg} / \mathrm{h}$ and determined using radiolabeled thymine. ${ }^{12}$

\section{Antioxidant capacity}

In order to quantify the effect of chemotherapy on patients' plasma antioxidant capacity we have analyzed the distribu- 
tion of its radical scavenging activity (RSA, \%) and ferric reducing ability before and after the first infusion in the applied treatment regimens (Fig. 1).

The observed RSA [\%], determined using the ABTS assay before the administration of 5-FU was in the interval between $35.46 \%$ and $50.06 \%$ (Fig. 1A). After the application of the treatment, the lowest and highest values of RSA were, respectively, $36.82 \%$ and $48.87 \%$. The estimated mean values from these results were $43.17 \%$ before and $43.02 \%$ after the infusion. Comparing the means of the two groups of dependent samples we see that they are statistically identical in the two related groups (before and after chemotherapy) $(p=0.62)$.

The obtained data from the FRAP assay before 5-FU administration indicate that the ferric reducing ability expressed as $\mathrm{mM} \mathrm{Fe} \mathrm{II}^{\mathrm{II}}$ equiv. was ranging from $0.29 \mathrm{mM}$ to $0.79 \mathrm{mM}$ (Fig. 1B). After the drug administration the lowest and the highest values were, respectively, $0.26 \mathrm{mM}$ and $0.70 \mathrm{mM}$. The estimated mean values were $0.48 \mathrm{mM}$ and $0.45 \mathrm{mM}$. Comparing the means of the two groups of dependent samples this time, we observe statistically significant change $(p<0.0001)$ indicating alterations in the $\mathrm{mM}$ $\mathrm{Fe}^{\mathrm{II}}$ equiv. after the applied treatment. The effect consists in

\section{$\mathbf{A}$}

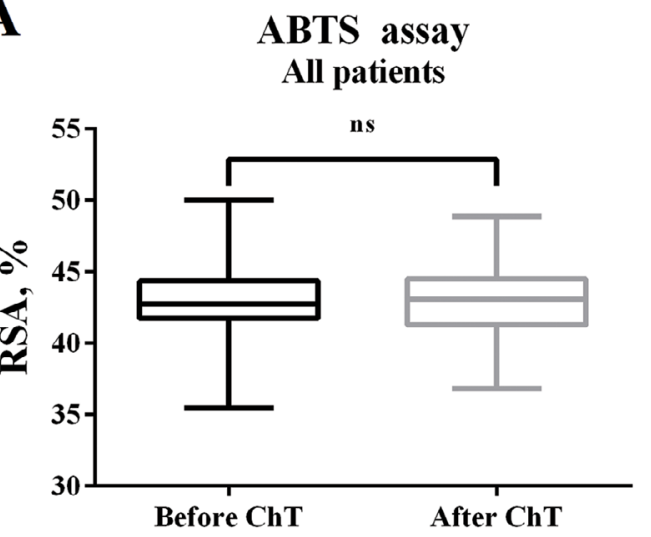

B

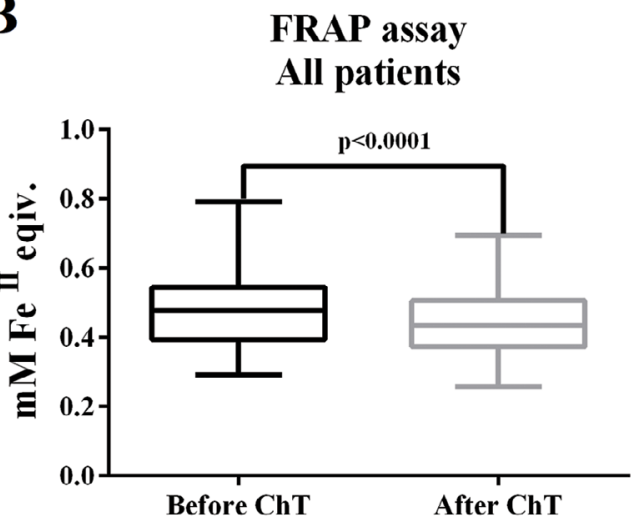

Figure 1. Distribution of patients' plasma radical scavenging activity and ferric reducing ability. Parameters' values before and after administration of the chemotherapeutic treatment, determined using ABTS (A) and FRAP (B) assays, are shown. $p<0.05$ was considered to indicate statistical significance. a decrease of the plasma capability to convert ferric-tripyrydyltriazine complex (Fe $\left.\mathrm{F}^{\mathrm{III}} \mathrm{TPTZ}\right)$ to its ferrous form.

As a next step, we followed the effect of the applied treatment on the determined antioxidant capacity using the ABTS and FRAP assay in relation to patients' DPD level. In the three subgroups presented in Fig. 2, when applying the ABTS assay, we did not observe conversion of the witnessed lack of statistically significant effect presented in Fig. 1. The observed $p$ values were $0.40,0.18$, and 0.60 for patients' plasma in group I, group II, and group III, respectively.
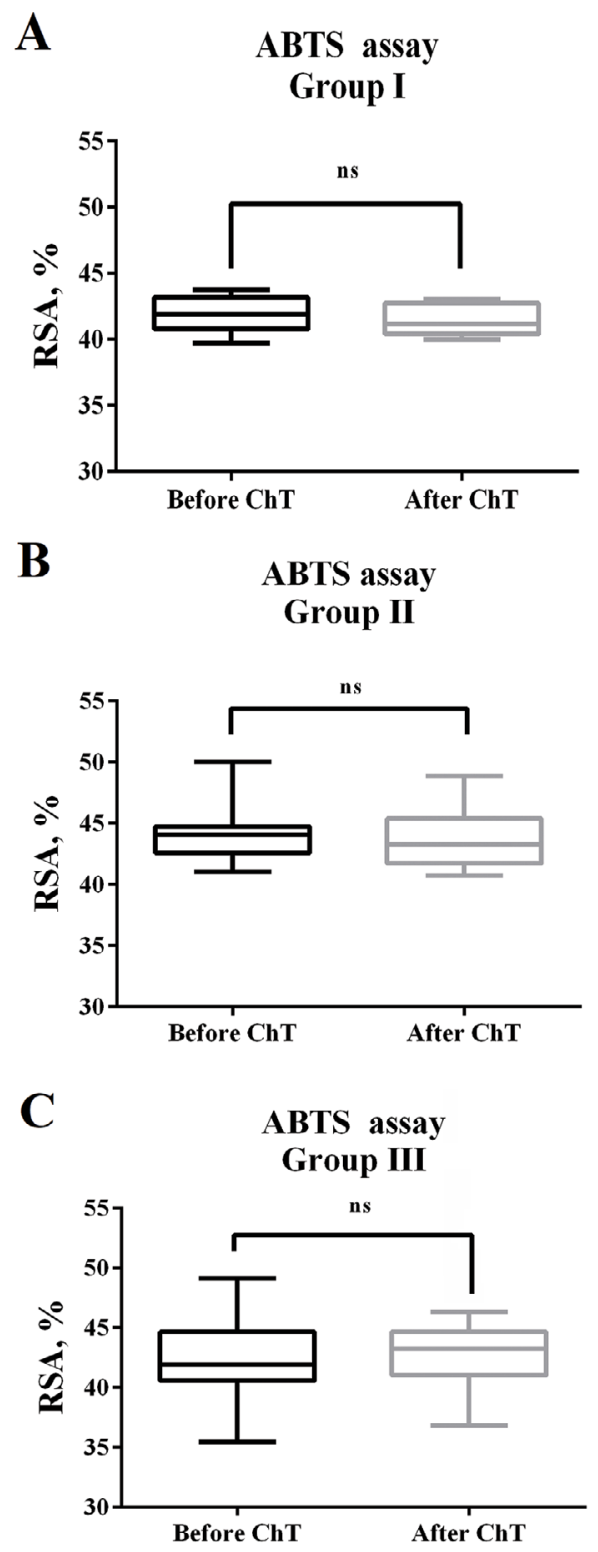

Figure 2. Distribution of patients' plasma radical scavenging activity. Parameters values, determined using the ABTS assay, before and after the administration of chemotherapeutic treatment are shown, divided in groups according to their DPD level. A. Group I: patients with DPD below $0.15 \mathrm{ng} / \mathrm{ml}$; B. Group II: patients with DPD in the interval 0.15 to $0.39 \mathrm{ng} / \mathrm{ml}$; C. Group III: patients with DPD higher than $0.39 \mathrm{ng} / \mathrm{ml} . p<0.05$ was considered to indicate statistical significance. 
In the FRAP system, the effect after the applied treatment varied depending on the DPD level. In group I the mean values of the group of samples before and after were, respectively, 0.47 and $0.45 \mathrm{mM} \mathrm{Fe} \mathrm{II}^{\mathrm{II}}$ equiv. and no statistically significant difference between the mean values was observed ( $p=0.81$ ) (Fig. 3). In groups II and III, where

\section{A}

\section{FRAP assay Group I}

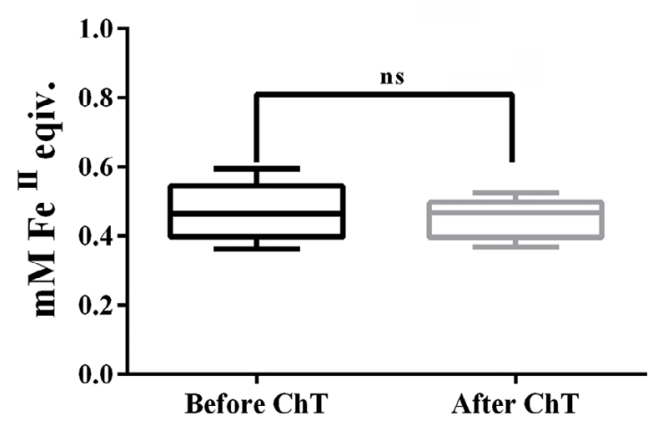

B

FRAP assay

Group II

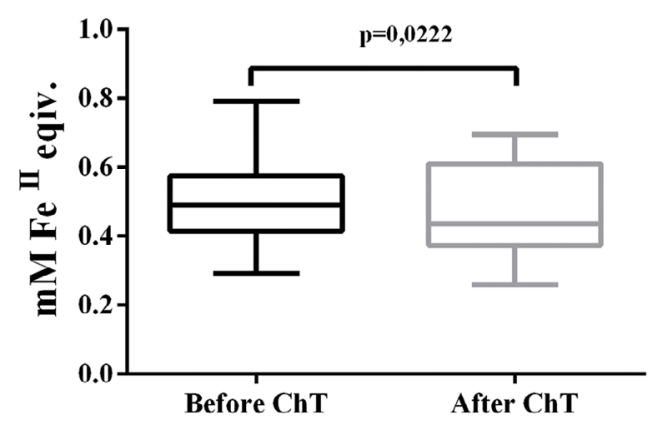

C

FRAP assay Group III

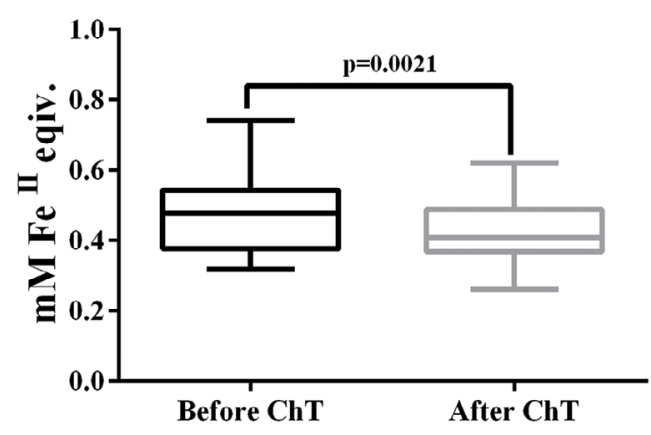

Figure 3. Distribution of patients' plasma ferric reducing ability. Parameters' values, determined using the FRAP assay, before and after the administration of the chemotherapeutic treatment are shown, divided in groups according to their DPD level. A. group I: patients with DPD below $0.15 \mathrm{ng} / \mathrm{ml}$; B. group II: patients with DPD in the interval 0.15 to $0.39 \mathrm{ng} / \mathrm{ml}$; C. group III: patients with DPD higher than $0.39 \mathrm{ng} / \mathrm{ml}$. $p<0.05$ was considered to indicate statistical significance. we had higher DPD levels, we observed conversion of the effect compared to group I, i.e. statistically significant decrease of the mean plasma ferric reducing ability after the infusion of 5-FU. In group II, the plasma ferric reducing ability decreased from $0.51 \mathrm{mM}$ to $0.47 \mathrm{mM} \mathrm{Fe}^{\mathrm{II}}$ equiv. $(p=0.022)$ and in group III from $0.46 \mathrm{mM}$ to $0.43 \mathrm{mM} \mathrm{Fe}^{\mathrm{II}}$ equiv. $(p=0.0021)$.

\section{DISCUSSION}

ROS generation within normal physiological ranges takes place in all living organisms. There is substantial scientific evidence suggesting redox dyshomeostasis, altered scavenging capacity of biological fluids and increased free radical generation are phenomenologically related to different events associated with oncological disease development and treatment. Increased generation of free radicals is crucial for tumor cell proliferation, angiogenesis, cancer cell migration and metastatic processes which are essential for cancer development and disease progression. Conversely, it is also one of the basic chemotherapeutic strategies for cellular damage and induced necrosis of the malignant cells. ${ }^{13}$ This complicated dual role has made the use of methods based on the estimation of the cumulative effect of all plasma components an appropriate strategy which may provide relevant biological information when combined with patients' individual clinical and histopathological features.

We have applied different spectrophotometric methods for estimation of plasma antioxidant capacity. Our results denoted that the determined effect on the alterations due the conducted treatment is different.

In the system using the biologically irrelevant (not naturally occurring in the human body), ABTS radical no statistically significant difference were observed between the determined scavenging activity before and after the treatment when evaluating all patients and regarding DPD concentration. This suggests no effect after the applied treatment on patients' plasma capability to decrease the concentration of the stable ABTS radical and, respectively, its scavenging activity.

On the contrary, according to the results obtained using the FRAP system after the applied treatment, a decrease of the ferric reducing ability of patients' plasma was observed. When studying the effect of the observed decrease of DPD levels, it is evident that for the patients' with DPD levels below $0.15 \mathrm{ng} / \mathrm{ml}$, the observed difference in the plasma ferric reducing capacity before and after treatment is not significant. With the increase of DPD levels, these differences become statistically significant: the $p$ values decrease and the statistical significance of the differences increases with the rise in DPD levels.

Observing different results when estimating the antioxidant capacity of biological samples and other types of probes is not uncommon and has been described by many authors. It results from the different indicators applied in 
the used systems and the estimation of diverse aspects. Due to this fact, it is recommendable to use more than one method - observing the reactivity of the sample components to be different against the varying indicators used in these systems suggests different contribution. According to literature data a possible decrease in the absorbance in the ABTS assay is due to human plasma antioxidants (mainly albumin and uric acid, respectively, 43-53\% and $33 \%$ of the total value, and ascorbic acid, $\alpha$-tocopherol and bilirubin). ${ }^{14}$ ABTS assay results have also been proven to be associated with the levels of endogenous glutathione ${ }^{15}$, while the FRAP assay - with plasma levels of ascorbic acid, uric acid, and $\alpha$-tocopherol. ${ }^{11}$ The antioxidant effects of uric acid, bilirubin, vitamin C, Trolox, and polyphenols can be determined using the FRAP assay but the effects of proteins using this method are weak. ${ }^{16}$

Many studies have proven decreased total antioxidant status (TAS) level, determined using the ABTS assay, but only when comparing the cancer patients with different oncolocalization and healthy controls. ${ }^{17,18}$ The experiments of $\mathrm{Wu}$ and coworkers proved this tendency for colorectal cancer patients. But when they studied the effect of the different clinical stages, the number of metastatic sites and compared preoperative and postoperative TAS levels of the plasma of colorectal patients using the ABTS assay, the parameter did not differ significantly. ${ }^{19}$ The obtained results in the ABTS system are also in accordance with previously performed experiments, where we investigated the changes after the application of combined chemotherapeutic regimens including cisplatin with irinotecan or gemcitabine on lung cancer patients. There we observed minor alteration of this parameter after the applied chemotherapeutic treatment using the ABTS assay and lack of statistically significant alterations in the total antioxidant capacity of patients' plasma. $^{20}$

Estimations of the ferric reducing ability of patients' plasma performed by another research group have also demonstrated a decrease after the chemotherapy when comparing with healthy controls. ${ }^{21}$ Other studies of the effect of another type of chemotherapeutic regimens containing 5-FU on the total antioxidant capacity of breast cancer patients and EJ138 cell medium proved a statistically significant decrease of the ferric reducing ability, depending on the number of the performed infusions and the incubation time. ${ }^{22}$ In our experiments, we noticed that ferric reducing ability exerts DPD-concentration-related changes when compared to its extent before the applied treatment.

A possible speculation concerning the explanation of the obtained results could be a weakened antioxidant barrier due to an increased reactive oxygen species production, overwhelming the antioxidant protection - a characteristic associated with the conducted treatment and drug metabolization. The overwhelmed antioxidant protection is more noticeable and affected to a higher extent with regard to the nonprotein antioxidant capacity. It is associated with the varying DPD levels known to influence 5-FU antitumor effectiveness, pharmacokinetics, bioavailability and toxicity.

\section{CONCLUSIONS}

Based on the aforementioned observations, it could be concluded that some aspects of plasma antioxidant capacity and individuals' antioxidant status might be involved in the pathogenesis of the disease and could be altered by the activity of some enzymes. The cancer therapy in question, by the specificity of its mechanism of action, can modify patient's oxidative status.

\section{Acknowledgements}

This work is supported by CMS of Medical University of Sofia, Sofia under contract D-98/24.06.2020 and the Bulgarian Ministry of Education and Science under the National Program for research "Young Researchers and Postdoctoral Students".

\section{REFERENCES}

1. Haggar FA, Boushey RP. Colorectal cancer epidemiology: incidence, mortality, survival, and risk factors. Clin Colon Rectal Surg 2009; 22(4):191-97.

2. Mármol I, Sánchez-de-Diego C, Pradilla Dieste A, et al. Colorectal carcinoma: a general overview and future perspectives in colorectal cancer. Int J Mol Sci 2017; 18(1):197.

3. Ballinger AB, Anggiansah C. Colorectal cancer. BMJ 2007; 335(7622):715-8.

4. Perše M. Oxidative stress in the pathogenesis of colorectal cancer: cause or consequence? Biomed Res Int 2013; 2013:725710.

5. Kocot J, Kiełczykowska M, Dąbrowski W, et al. Total antioxidant status value and superoxide dismutase activity in human colorectal cancer tissue depending on the stage of the disease: a pilot study. Adv Clin Exp Med 2013; 22(3):431-7.

6. Vodenkova S, Buchler T, Cervena K, et al. 5-fluorouracil and other fluoropyrimidines in colorectal cancer: Past, present and future. Pharmacol Ther 2020; 206:107447.

7. Güçlü H, Doganlar ZB, Gürlü VP, et al. Effects of cisplatin-5-fluorouracil combination therapy on oxidative stress, DNA damage, mitochondrial apoptosis, and death receptor signalling in retinal pigment epithelium cells. Cutan Ocul Toxicol 2018; 37(3):291-304.

8. Matsubara I, Kamiya J, Imai S. Cardiotoxic effects of 5-fluorouracil in the guinea pig. Jpn J Pharmacol 1980; 30(6):871-9.

9. Muneoka K, Shirai Y, Yokoyama N, et al. 5-fluorouracil cardiotoxicity induced by alpha-fluoro-beta-alanine. Int J Clin Oncol 2005; 10(6): 441-3.

10. Re R, Pellegrini N, Proteggente A, et al. Antioxidant activity applying an improved ABTS radical cation decolorization assay. Free Radic Biol Med 1999; 26(9-10):1231-7.

11. Benzie IF, Szeto YT. Total antioxidant capacity of teas by the ferric reducing/antioxidant power assay. J Agric Food Chem 1999; 47(2): 633-6.

12. Van Kuilenburg AB, Haasjes J, Richel DJ, et al. Clinical implications of dihydropyrimidine dehydrogenase (DPD) deficiency in patients with severe 5-fluorouracil-associated toxicity: identification of new mutations in the DPD gene. Clin Cancer Res 2000; 6(12):4705-12. 
13. Ivanova $\mathrm{D}$, Bakalova $\mathrm{R}$, Lazarova $\mathrm{D}$, et al. The impact of reactive oxygen species on anticancer therapeutic strategies. Adv Clin Exp Med 2013; 22(6):899-908.

14. Miller NJ, Rice-Evans C, Davies MJ, et al. A novel method for measuring antioxidant capacity and its application to monitoring the antioxidant status in premature neonates. Clin Sci 1993; 84:407-12.

15. Kang M, Saltveit E. Antioxidant capacity of lettuce leaf tissue increases after wounding. J Agric Food Chem 2002; 50:7536-41.

16. Erel O. A novel automated direct measurement method for total antioxidant capacity using a new generation, more stable ABTS radical cation. Clin Biochem 2004; 37:277-85.

17. Feng JF, Lu L, Zeng P, et al. Serum total oxidant/antioxidant status and trace element levels in breast cancer patients. Int J Clin Oncol 2012; 17(6):575-83.

18. Wang D, Feng JF, Zeng P, et al. Total oxidant/antioxidant status in sera of patients with thyroid cancers. Endocrine-Related Cancer 2011;
18:773-82.

19. Wu R, Feng J, Yang Y, et al. Significance of serum total oxidant/antioxidant status in patients with colorectal cancer. PLoS One 2017; 12(1):e0170003.

20. Robev B, Hristova-Avakumova N, Nikolov R, et al. Effect of chemotherapy on the oxidative status of patients with small cell lung cancer. Proceedings of Conference " 15 years of pharmacy studies at the Medical University of Plovdiv” - 01-03 June 2018. Devin p. 144-148. ISBN 978-619-237-014-5

21. Zińczuk J, Maciejczyk M, Zaręba K, et al. Antioxidant barrier, redox status, and oxidative damage to biomolecules in patients with colorectal cancer. Can malondialdehyde and catalase be markers of colorectal cancer advancement? Biomolecules 2019; 9(10):637.

22. Singh G, Maulik S, Jaiswal A, et al. Effect on antioxidant levels in patients of breast carcinoma during neoadjuvant chemotherapy and mastectomy. Malays J Med Sci 2010; 17(2):24-8. 


\title{
Изменяет ли уровень дигидропиримидин дегидрогеназы антиоксидантную способность плазмы у пациентов с колоректальным раком, получавших фрторпиримидины?
}

\author{
Велко Минчев ${ }^{1}$, Надя Христова-Авакумова ${ }^{2}$, Калина Каменова $^{3}$, Лилия Атанасова ${ }^{2}$, \\ Марин Ангелов ${ }^{1}$, Лозан Тодоров ${ }^{4}$, Славина Сурчева ${ }^{5}$, Румен Николов $^{5}$ \\ ${ }^{1}$ Отделение онкологии, УМБАЛ „Софиямед“, София, Болгария \\ ${ }^{2}$ Кафедра медицинской физики и биофизики, Медицинский университет - София, София, Болгария \\ ${ }^{3}$ Кафедра медицинской химии и биохимии, Медицинский университет - София, София, Болгария \\ ${ }^{4}$ Кафедра химии, Фармацевтический факультет, Медицинский университет - София, София, Болгария \\ ${ }^{5}$ Кафедра фармакологии и токсикологии, Медииинский факультет, Медицинский университет - София, София, Болгария
}

Адрес для корреспонденции: Надя Христова - Авакумова, Кафедра медицинской физики и биофизики, Медицинский университет София, София, Болгария; E-mail: nadia_hristova@abv.bg; Тел.: +359885848954

Дата получения: 4 августа 2020 Дата приемки: 21 октября 2020 Дата публикации: 31 октября 2021

Образец цитирования: Minchev V, Hristova-Avakumova N, Kamenova K, Atanasova L, Angelov M, Todorov L, Surcheva S, Nikolov R. Does dihydropyrimidine dehydrogenase level modify plasma antioxidant capacity in colorectal cancer patients treated with fluoropyrimidines? Folia Med (Plovdiv) 2021;63(5):760-7. doi: 10.3897/folmed.63.e57234.

\section{Резюме \\ Введение: Колоректальный рак - третий по распространённости вид рака во всём мире. Фторпиримидины и схемы на ос- нове их пролекарств широко используются в качестве основных лекарственных средств. Основным ферментом, ответствен- ным за фактор, ограничивающий скорость пиримидина, и за катаболизм 5-фторурацила, является дигидропиримидиндеги- дрогеназа (ДПД).}

Цель: Наша цель состояла в том, чтобы проверить уровни ДПД и изменения антиоксидантной активности в плазме у пациентов с колоректальным раком, получающих 5-фторурацил.

Материалы и методы: В исследовании использовали набор Elisa для ДПД человека, основанный на иммуноферментных анализах и спектрофотометрических методах (FRAP и ABTS).

Результаты: Не было обнаружено статистически значимых различий в активности очистки плазмы согласно результатам, полученных с помощью системы ABTS, после оценки всех пациентов и с учетом концентрации ДПД. Отмечалось снижение способности снижать содержание железа в плазме у пациентов, принимавших после лечения. Повышение уровня ДПД сопровождается уменьшением значений $p$, поэтому статистическая значимость различий возрастает.

Заключение: На основании вышеприведённых наблюдений можно сделать вывод о том, что некоторые аспекты антиоксидантной способности плазмы и индивидуального антиоксидантного статуса могли играть роль в патогенезе заболевания и могут быть изменены активностью определённых ферментов. Обсуждаемая противоопухолевая терапия может изменять окислительный статус пациента за счет специфичности механизма её действия.

\section{Ключевые слова}

ABTS, колоректальный рак, дигидропиримидиндегидрогеназа, фторпиримидины, FRAP 